\title{
Taxpaying Made Easy
}

\section{Andrew Leigh}

S uppose that the Australian government decided that once a year, it would ask everyone to fill out a set of forms setting out their status. University students would be required to write down where they went to university, which courses they took, and who taught those courses. Anyone who had used medical services would have to tell the government which doctor they went to, and why. Anyone working for the government would have to fill out a form stating what job they did, and how much they earned. Veterans would have to tell the government what war they fought in, and for how many years. For the average person, the whole process would take eight hours, or a full working day.

If this sounds to you like an inefficient way of collecting data, then consider that the process of filing tax returns in Australia is not much different. Each year, the Australian taxation system requires two-thirds of the adult population to spend an average of eight hours (Tran-Nam et al, 2000) telling the government basically what it already knows. Much of the information in our tax returns is already held in government databanks - to a large extent, the current process involves us producing figures that are then cross-checked against them.

While the administrative burden of small business regulations has been accorded serious attention in policy debates, less notice has been taken of the administrative burden that falls on individual taxpayers. This article argues that by following the example of New Zealand, we could significantly reduce the administrative burden on ordinary taxpayers. Most importantly, the change need not involve any change to tax rates or brackets. One of the barriers that has stood in the way of simplifying the tax filing system is the misperception among some policymakers that making filing easier must involve changing tax rates. Recognising that changing the filing system can be kept conceptually distinct from changing tax rates, tax simplification can be supported by those who believe that tax rates should be higher, lower, or just the same as they are today.

\section{The Other Deadweight Cost of Taxation}

Most tax reform plans are focused on cutting top tax rates. The theory behind this is simple: since income taxes deter work, they impose a 'deadweight cost'. But reducing tax rates (without changing the tax base) has another consequence: it typically means that there is less revenue available to pay for national security,

Andrew Leigh is Fellow Social Policy Evaluation, Analysis and Research, Centre Research School of Social Sciences, The Australian National University. 
unemployment benefits, schools, pensions, hospitals and roads ${ }^{1}$. Survey evidence indicates that most Australians acknowledge this trade-off. They recognise that taxes reduce work, but by a small margin, they prefer more social spending to lower tax rates (Leigh, 2006).

What is often missed in Australian tax debates is that reduced work incentives are not the only deadweight cost of taxation. As everyone who spends the last weekend in October filling in tax forms knows, another deadweight cost of taxation is the administrative burden. Getting your receipts in order for the tax agent or ploughing through the Tax Pack takes time that could be spent doing more productive activities. In 2003-04, the most recent year for which taxation statistics are available, two-thirds of Australian adults filed a tax return (Figure 1). By contrast, just one in five adults in the United Kingdom currently fill in tax returns (number of UK taxpayers from Evans, 2004; UK adult population data from Statistics UK). In most OECD countries, the majority of adults are not required to complete an annual tax return (Owens, 2005).

\section{Figure 1: Tax Filing in Australia}

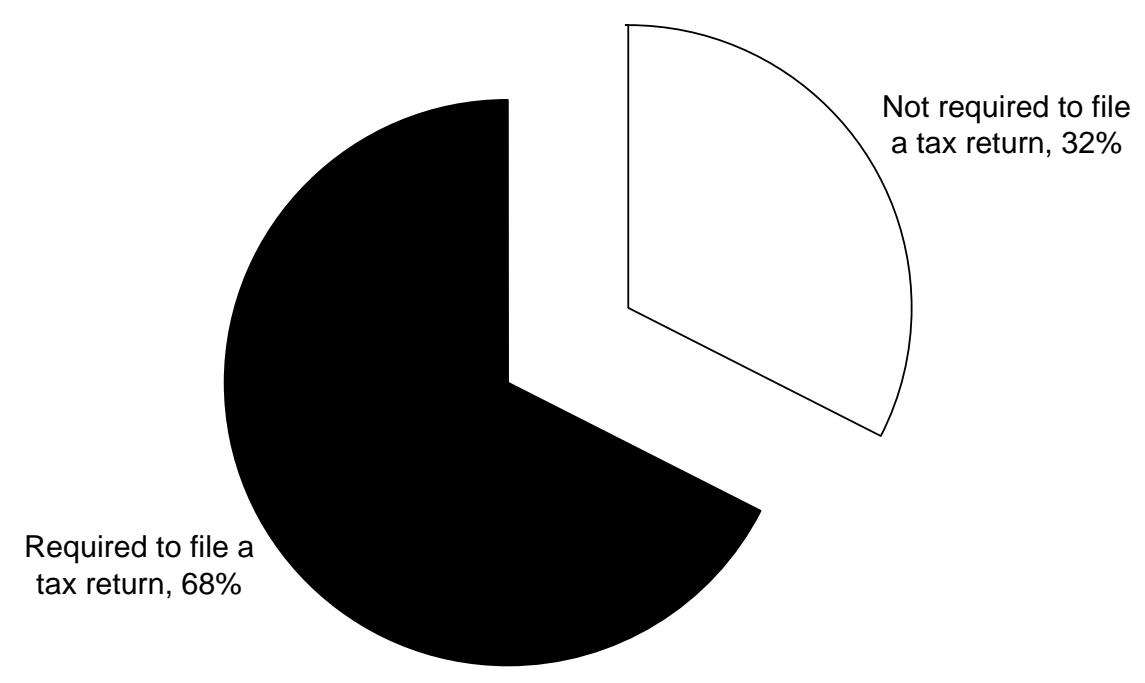

How much time do we take to do our taxes? In 1994-95, Binh Tran-Nam and his co-authors surveyed a representative group of Australian taxpayers, and asked them how much time they took to complete their returns (Tran-Nam et al, 2000). On average, they found that Australian personal taxpayers spent $81 / 2$ hours each year on their tax affairs. Multiplying this by their hourly wage rate, they found that tax compliance costs each taxpayer around $\$ 210$. The authors noted that their estimates of tax compliance costs as a share of tax revenue were similar to

\footnotetext{
${ }^{1}$ The negative relationship between tax rates and revenue does not hold for a country on the wrong side of the so-called Laffer Curve (see Fullerton, 1980; Laffer, 1981; Stuart 1981; Davidson, 2005).
} 
an earlier Australian study using data from 1986-87 (Pope, Fayle and Duncanson, 1990). Both estimates indicated that the taxpayer compliance burden in Australia - as a share of tax revenue - was several times higher than the taxpayer compliance burden in the UK (Sandford, 1995).

There is little reason to think that the tax compliance costs estimated by Tran-Nam and his co-authors should have fallen significantly over the past decade. For one thing, the share of taxpayers filing through a tax agent has remained unchanged. In both 1994-95 (the year of their survey) and 2003-04 (the most recent year for which data are available), 74 percent of Australian taxpayers used a tax agent (ATO Taxation Statistics, 1994-95:Table P18; ATO Taxation Statistics, 2003-04:Personal Tax Table 4A). Perhaps the advent of electronic filing saved some time ( 9 percent of taxpayers filed electronically in 2003-04), and more recent innovations such as a shorter tax return and filing by phone may also have helped a little. But these are unlikely to have drastically cut overall taxpayer compliance costs. Converting the estimates of Tran-Nam et al. (2000) into today's wages gives a figure of $\$ 346$ per taxpayer (based on the increase in average weekly ordinary time earnings for full-time adults from financial year 1994-95 to June 2006). This means that the cost to taxpayers of complying with the personal income taxation system is around $\$ 3.7$ billion per year.

\section{Figure 2: Tax Filing in New Zealand}

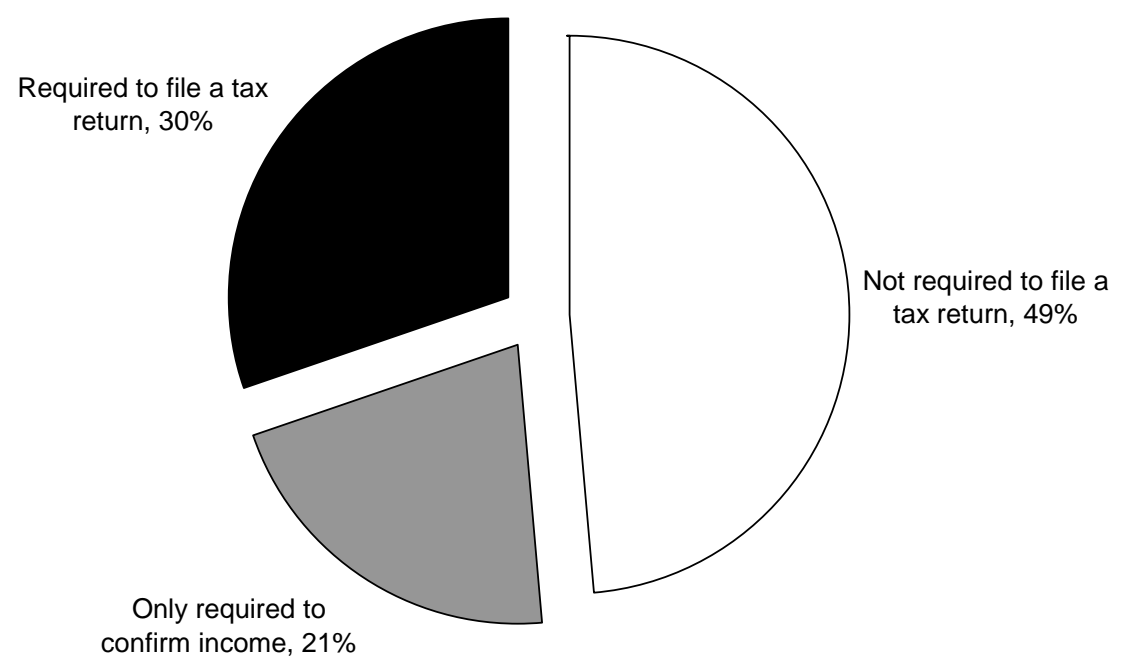

To see how we could reduce the cost of tax compliance, we only have to look across the Tasman. Back in the mid-1990s, three-quarters of New Zealand adults were required to complete tax returns. Following a major report on tax compliance (McKay et al., 1998), New Zealand dramatically simplified its tax system in 1999, freeing most adults from the requirement of filling in tax returns (Birch, 1998; Inland Revenue, 1999). As Figure 2 shows, in the most recent tax 
year, half of all adult New Zealanders - those whose only sources of income were wages, interest or dividends - were not required to complete a return. Another one-fifth receive a statement from the tax office setting out what the authorities thought they owed, which they had to correct or confirm (this can be done with a telephone call). Only three in ten New Zealand taxpayers now complete tax returns. $^{2}$

\section{Pre-Population}

One reason the New Zealand tax system allows nearly three-quarters of personal taxpayers not to complete a return is that theirs is a simpler tax system than ours. Many of the tax deductions available in Australia do not exist in New Zealand. Indeed, some have argued that Australia should follow New Zealand in abolishing many of the deductions that are currently available, and lowering overall tax rates. Proposals to 'broaden the base and lower the rates' make a good deal of economic sense, but invariably involve plenty of jockeying, as special interests fight to preserve their favourite tax break.

However, we can make life easier for Australian taxpayers without doing anything so radical. A much simpler reform would be as follows. In August of each year the Australian Taxation Office (ATO) - knowing how much each taxpayer earned from various sources - could send out tax statements, setting out each person's income and tax liability. ${ }^{3}$ In other words, the tax forms could be 'pre-populated' with the information already held by the ATO. If a taxpayer then wished to claim certain deductions, they would be free to fill in a tax return. But if not - and provided the taxpayer's only income is from wages, dividends and interest - they would have the option of not filing a tax return. All the taxpayer would then have to do is let the ATO know that he or she agrees with the assessment, and then claim a refund or pay the excess tax. Plenty of taxpayers may choose to forfeit deductions to which they are entitled in exchange for avoiding the hassle of filing a tax return. Indeed, the rise in tax revenue from these forfeited deductions is likely to outweigh any increase in administrative costs for the ATO in moving towards a system of pre-population. Current ATO initiatives (see ATO, 2006 for details) could form the basis for such a transition.

Simplification could not take everyone out of the personal tax system. Selfemployed workers, landlords, and others with 'complex income' would still have to complete a tax return. But like New Zealand, we could spare around threequarters of current Australian taxpayers from wrestling with the Tax Pack, from keeping receipts through the year, and from fretting as 31 October looms.

\footnotetext{
${ }^{2}$ These figures are calculated from data supplied via email by Sandra Watson of the New Zealand Inland Revenue - Te Tari Taake (11 October 2005). On the impact of the New Zealand reforms, see also Evans (2004).

${ }^{3}$ As part of this system, it might make sense to withhold tax from interest and dividend payments at source, as is presently done for wage and salary income. Under the current Medicare levy system, it would also be necessary for taxpayers with private health insurance to inform the ATO of their fund details (though this would not necessarily have to be updated on an annual basis).
} 


\title{
A Conversation, Not a Crusade
}

Writing in the New York Times, US economist Joel Slemrod (2005) noted that calls for tax reform are invariably radical, but radicalism is not always required:

\begin{abstract}
Contemplation of radical tax alternatives is exhilarating, and could help to avoid the kind of loophole-to-loophole combat that tax war veterans recall from 1986, the last time we made wholesale changes in the system. But much progress toward these goals - including eliminating the need for most Americans to file tax returns - can be made within the basic framework of the current system. ... [Some proposals] are calls to join a crusade. We'd be better off just starting a conversation.
\end{abstract}

Radical tax reformers often argue that their proposals will reduce the need for many people to complete a tax return. As a consequence, those watching the debate often develop the mistaken impression that the only ways to reduce the number of tax filers are to cut rates and abolish deductions, or raise the tax-free threshold. Yet the beauty of removing the requirement for most Australians to complete tax returns is that it can be implemented with any set of tax rates and tax brackets. Simplifying the filing system should be simultaneously on the agenda of those who believe that the tax system should be more progressive than it is today, and those who believe the tax system should be made more regressive. Recognising this, it is difficult to see why reducing the number of tax filers does not command bipartisan political support.

In an era when the ATO deducts most tax at source, it is difficult to see why the typical Australian should spend a full working day every year telling the tax office what it already knows. Instead, it would be better to exempt most taxpayers from the requirement to complete a tax return, so long as the ATO already knows about all the income that they have earned. By saving taxpayers eight hours of work, such a reform would give most Australians the equivalent of an extra public holiday each year. For most Australians, October 31 would be just another day.

Over the past few years, Australian policymakers have focused attention on reducing top marginal income tax rates. Instead, we should focus on making the tax system simpler for ordinary Australians. Like New Zealand, Australia could dramatically simplify the tax filing system, saving many of us the hassle of a day doing taxes, and reducing the $\$ 3.7$ billion deadweight cost of the personal income tax system that comes from compliance costs alone.

\section{References}

Australian Taxation Office (2006), Making it Easier to Comply, NAT 9497-01, ATO, Canberra.

Birch, B. (1998), Taxation (Simplification and Other Remedial Matters) Bill; Commentary on the Bill, Policy Advice Division of the Inland Revenue Department, Wellington.

Davidson, S. (2005), 'Are There Any Good Arguments Against Cutting Income Taxes?', CIS Policy Monograph 69, Centre for Independent Studies, Sydney. 
Evans, C. (2004), 'Diminishing Returns: The Case for Reduced Annual Filing for Personal Income Taxpayers in Australia', Australian Tax Review 33:168-181.

Fullerton, D. (1980), 'On the Possibility of an Inverse Relationship Between Tax Rates and Government Revenues', Journal of Public Economics 19:3-22.

Inland Revenue (Te Tari Taake) (1999), Supplementary Briefing Papers. Volume 1: Tax Policy, Inland Revenue, Wellington.

Laffer, A.B. (1981), 'Government exactions and revenue deficiencies', Cato Journal $1(1): 1-21$.

Leigh, A. (2006), 'Political Economy of Tax Reform in Australia', Public Policy 1(1):52-60.

McKay, I., T. Molloy, J. Prebble and J. Waugh (1998), Tax Compliance: A Report to the Treasurer and Minister of Revenue by a Committee of Experts on Tax Compliance, New Zealand Government, Wellington (available at http://www.executive.govt.nz/9699/compliance/index.html)

Owens, J. (2005), 'Fundamental Tax Reform: The Experience of OECD Countries', Tax Foundation Background Paper 47, Tax Foundation, Washington DC.

Pope, J., R. Fayle and M. Duncanson (1990), The Compliance Costs of Personal Income Taxation in Australia 1986-87, Australian Tax Research Foundation, Sydney.

Sandford, C. (1995), Tax Compliance Costs: Measurement and Policy, Fiscal Publications, Bath.

Slemrod, J. (2005), 'The Fairtax Book' and 'Flat Tax Revolution': 1040EZ - Really, Really EZ', New York Times. November 13.

Stuart, C. (1981), 'Swedish Tax Rates, Labor Supply, and Tax Revenues', Journal of Political Economy 89: 1020-1038.

Tran-Nam, B., C. Evans, K. Ritchie and M. Walpole (2000), 'Tax Compliance Costs: Research Methodology and Empirical Evidence from Australia' National Tax Journal 53(2):229-252.

Thanks to Fred Argy, Mark Bahnisch, Chris Evans, Nicholas Gruen, Peter Kenyon, John Quiggin and two anonymous referees for valuable comments on an earlier draft. These people should not be assumed to agree with the contents of this paper. 